\title{
Assessment of morphometric parameters of Khulgad watershed using geographical information system and remote sensing
}

\author{
RAJDEV PANWAR, PANKAJ KUMAR, KAPIL PANDEY, ABHINAV KANDPAL AND DEVENDRA \\ KUMAR
}

Received : 16.02.2017; Revised : 17.03.2017; Accepted : 24.03.2017

See end of the Paper for authors' affiliation

Correspondence to :

\section{RAJDEV PANWAR}

Department of Soil and Water Conservation Engineering,

G.B. Pant University of Agriculture and Technology, PANTNAGAR (UTTARAKHAND) INDIA

Email : rajdevpanwar22@ gmail.com
-ABSTRACT : Khulgad watershed is the constituent of the Kosi river basin and is located to the west of the Almora town in the Hawalbagh Development Block of Almora district in the Uttarakhand. The watershed is bounded within $79^{\circ} 32^{\prime} 20.71^{\prime \prime}$ to $79^{\circ} 37^{\prime} 11.19^{\prime \prime}$ E longitude and $29^{\circ} 34^{\prime} 30.20^{\prime \prime}$ to $29^{\circ} 38^{\prime} 48.03$ ' N latitude, covering an area of $32.57 \mathrm{~km}^{2}$ and having cool temperature climate with an annual average temperature of $20^{\circ} \mathrm{C}$. To achieve the Morphometric analysis, toposheet No. $63 \mathrm{C} /$ 2 Survey of India (SOI) in 1:50000 scales are procured and the boundary line is extracted by joining the ridge points. This will serve as area of interest for preparing base map and thematic maps. The drainage map is prepared with the help of geographical information system tool and morphometric parameters such as linear, aerial and relief aspects of the watershed have been determined. These dimensionless and dimensional parametric values are interpreted to understand the watershed characteristics. From the drainage map of the study area dendritic drainage pattern is identified. Strahler (1964) stream ordering method is used for stream ordering of the watershed. The mean bifurcation ratio of the watershed is 3.49 .

KEY WORDS : Khulgad watershed, GIS, Remote sensing, Morphometric parameters (linear, areal, relief)

- HOW TO CITE THIS PAPER : Panwar, Rajdev, Kumar, Pankaj, Pandey, Kapil, Kandpal, Abhinav and Kumar, Devendra (2017). Assessment of morphometric parameters of Khulgad watershed using geographical information system and remote sensing. Internat. J. Agric. Engg., 10(1) : 133-140, DOI: 10.15740/HAS/ IJAE/10.1/133-140. 